\title{
PENGARUH KEPEMIMPINAN, KOMUNIKASI, DAN KOMPETENSI TERHADAP KEPUASAN KERJA (Studi Pada Karyawan SMK Muhammadiyah 4 Jakarta)
}

\author{
Hendri Jopanda, SE., M.Si*) \\ hjopanda@yahoo.com \\ *Dosen Tetap FEB Universitas Satya Negara Indonesia Jl.Arteri Pondok Indah No.11 Jakarta.
}

\begin{abstract}
ABSTRAK
Penelitian ini bertujuan untuk mengetahui Pengaruh Kepemimpinan, Komunikasi, dan Kompetensi Terhadap Kepuasan Kerja Karyawan SMK Muhammadiyah 4 Jakarta. Populasi dalam penelitian ini adalah karyawan SMK Muhammadiyah 4 sebanyak 50 orang. Teknik pengambilan sampling yang digunakan teknik nonprobability sampling. Sampel penelitian ini adalah 50 responden. Teknik analisis data yang digunakan dalam penelitian ini adalah analisis regresi berganda. Hasil penelitian yang diperoleh bahwa simultan Kepemimpinan, Komunikasi, dan Kompetensi berpengaruh positif dan signifikan Terhadap Kepuasan Kerja Karyawan SMK Muhammadiyah 4, dan secara parsial Kepemimpinan, Komunikasi berpengaruh positif dan signifikan Terhadap Kepuasan Kerja Karyawan SMK Muhammadiyah 4. Sedangkan Kompetensi tidak berpengaruh signifikan Terhadap Kepuasan Kerja SMK Muhammadiyah 4. Sekolahan harus memberikan perhatian kepada Kepemimpinan, Komunikasi, dan Kompetensi yang akan meningkatkan Kepuasan Kerja Karyawan SMK Muhammadiyah 4 Jakarta.
\end{abstract}

\section{Kata Kunci: Kepemimpinan, Komunikasi, Kompetensi, Kepuasan Kerja}

\section{Latar Belakang}

Pendidikan menjadi salah satu faktor penting untuk memajukan suatu bangsa. Setiap bangsa sebaiknya memiliki pendidikan yang tinggi dan berkualitas, sehingga dapat digunakan untuk menciptakan sumber daya manusia yang berkualitas. Apabila suatu bangsa memiliki SDM yang berkualitas, tentunya mampu membangun bangsanya menjadi lebih maju. Suatu organisasi tentu mempunyai tujuan yang ingin dicapai. Dalam tujuan tersebut sebuah organisasi harus memperhatikan visi misi suatu organisasi tersebut agar tercapainya suatu tujuan. Suatu organisasi pasti memerlukan sumber daya manusia untuk membantu mewujudkan tujuannya. SDM yang dikembangkan dengan baik untuk mendapatkan hasil yang optimal dan menguntungkan perusahaan.

SMK Muhammadiyah 4 Jakarta harus selalu berlari mengikuti perkembangan zaman yang semakin cepat, diam akan sangat terbelakang dalam menalar dan mencerna efektifitas dan elektabilitas zaman, minimal pelajar dapat bergerak maju dan meminimalisir jalan ditempat tentang cara pandang dan befikir efektif untuk semua era millenial ini.SMK Muhammadiyah 4 Jakarta sebagai wadah dimana para pelajar sebagai peserta didik harus selalu ditekankan pentingnya kewirausahaan dan produktivitas berkarya sehingga menjadikan pelajar tersebut dapat menciptakan peluang usaha sekecil apapun.

Kepuasan kerja membawa manfaat bagi kepentingan individu, industri, dan masyarakat karena dapat membuat pekerja untuk meningkatkan produktivitas kerja. Sumber daya manusia menjadi peran utama dalam segala jenis kegiatan suatu usaha. Ketika seorang karyawan mendapatkan kepuasan dalam bekerja pastinya ia akan ingin lebih mengembangkan kemampuan yang dimilikinya untuk menyelesaikan tugas atau pekerjaannya. Bahwa kepuasan kerja adalah sikap yang dimiliki para pekerja tentang pekerjaan mereka. Hal itu merupakan hasil dari persepsi mereka tentang pekerjaan.

Fenomena yang terjadi sebagian karyawan berbeda terhadap fokus mereka dan merasa pekerjaan sekarang sudah cukup sehingga tidak merasa puas saat berada ditingkat pekerjaan yang 
lebih sulit dan berbeda. Menciptakan lingkungan kerja yang aman, nyaman serta kondusif saat jam bekerja sangat dibutuhkan agar para pekerja dapat fokus mengembangkan kemampuan yang dimilikinya untuk menyelesaikan tugas atau pekerjaannya sehingga setiap karyawan bisa menghasilkan pekerjaan sesuai dengan apa yang diharapkan pimpinan untuk mencapai kepuasan kerja.

Kepemimpinan yang memiliki wawasan yang lebih luas dan berwibawa sangat diperlukan dalam suatu organisasi untuk mengarahkan karyawan agar terus berkembang untuk mencapai sutau tujuan yang dimilikinya demi tercapainya kepuasan kerja. Pimpinan perlu berkomunikasi dengan baik kepada bawahan atau setiap karyawannya agar tidak terjadi kesalahan saat mengerjakan tugas atau perintah yang diberikan. Dalam usaha memenuhi harapan, pemimpin menggunakan kemampuan dan kecerdasannya dengan memanfaatkan lingkungan dan potensi yang ada pada organisasi. Dengan kata lain pemimpin berusaha melibatkan anggota organisasi untuk mencapai tujuan.

Fenomena yang terjadi Kepala Sekolah kurang jelas saat memberikan arahan atau tugas, setiap karyawan tidak mempunyai banyak kesempatan dalam menyampaikan pendapat atau menanyakan suatu pekerjaan yang kurang dipahami sehingga terjadinya kurang maksimal dalam mengerjakan tugas yang diberikan. Pimpinan kurang mengawasi terhadap pekerja yang terlalu cuek, maka kendala tersebut akan berakibat terhadap kepuasan kerja karyawan. Untuk mencapai suatu tujuan di dalam sebuah organisasi perlu membangun kebersamaan dengan mengikuti pengendalian dan kontrol internal yang dilakukan langsung oleh pimpinannya.

Komunikasi berperan penting demi kelancaran suatu organisasi. Karena suatu pekerjaan, karyawan tidak jauh dari komunikasi dengan pemimpin dan rekan kerja lainnya. Untuk menghasilkan pemahaman yang sama antara pengirim dan penerima informasi maka dibutuhkan komunikasi yang efektif sehingga tercapainya suatu tujuan organisasi, kepemimpinan juga sangat penting untuk meningkatkan kepuasan kerja.

Fenomena yang terjadi miskomunikasi terhadap para karyawan saat sedang menyampaikan pesan, mengalami ketidakcocokan pola pemikiran dan sering terjadi kekurang pahaman pada pesan yang disampaikan. Setiap karyawan sangat diperlukan komunikasi yang baik antara pimpinan dan rekan lainnya agar tercapainya suatu tujuan. Untuk mencapai kepuasan kerja tidak hanya meningkatkan kepemimpinan dan komunikasi kerja saja tetapi juga memerlukan kompetensi setiap karyawan.

Kompetensi memiliki hubungan dengan pendidikan, karena memiliki jenjang pendidikan yang tinggi dan memiliki banyak pengalaman seseorang untuk menghasilkan tingkat yang memuaskan di tempat kerja. Undang-Undang Republik Indonesia Nomor 13 Tahun 2003 Tentang Ketenagakerjaan mendefinisikan kompetensi sebagai kemampuan setiap individu yang mencakup pengetahuan, keterampilan, dan sikap kerja yang sesuai dengan standar yang ditetapkan. Kompetensi sangat diperlukan suatu organisasi agar tercapainya kepuasan kerja.

Fenomena yang terjadi sebagian karyawan merasa bahwa mengerjakan pekerjaan sesuai dengan kemampuan yang dimilikinya sudah cukup sehingga merasa kurang mampu saat menyelesaikan pekerjaan yang berbeda saat diberikan oleh pimpinan. Akan tetapi sebagian karyawannya merasa kurang puas akan kemampuan yang dimilikinya saat ini karena merasa sulit untuk mengerjakan pekerjaan saat pimpinan memberikan pekerjaan yang berbeda.

Hal-hal yang berkaitan dengan kepemimpinan, komunikasi dan kompetensi perlu mendapat perhatian untuk meningkatkan kinerja karyawan agar tercapainnya kepuasan kerja pada suatu organisasi. Sangatlah penting faktor kompetensi, komunikasi dan kepemimpinan terhadap kepuasan kerja adalah diharapkan dapat menemukan unsur-unsur mana saja yang perlu dikembangkan dan diperbaiki sehingga dapat meningkatkan kepuasan kerja karyawan. berikut:

Berdasarkan latar belakang di atas maka masalah penelitian ini dirumuskan sebagai

1. Apakah Kepemimpinan Berpengaruh Terhadap Kepuasan Kerja Karyawan SMK Muhammadiyah 4 Jakarta? 
2. Apakah Komunikasi Berpengaruh Terhadap Kepuasan Kerja Karyawan SMK Muhammadiyah 4 Jakarta?

3. Apakah Kompetensi Berpengaruh Terhadap Kepuasan Kerja Karyawan SMK Muhammadiyah 4 Jakarta?

4. Apakah Kepemimpinan, Komunikasi, dan Kompetensi Berpengaruh Terhadap Kepuasan Kerja Karyawan SMK Muhammadiyah 4 Jakarta?

\section{A. Landasan Teori}

\section{Kepuasan Kerja}

\section{a. Definisi Kepuasan}

Kepuasan adalah sifat yang dimiliki setiap individu. Rasa puas yang dirasakan bisa disebabkan oleh beberapa faktor baik secara langsung maupun tidak langsung. Dari uraian di atas definisi kepasan menurut para ahli sebagai berikut:

Menurut Weihrich, Koontz dalam Lijan Poltak Sinambela (2016:302) kepuasan merujuk pada pengalaman kesenangan atau kesukaan yang dirasakan oleh seseorang ketika apa yang diinginkan tercapai.

\section{b. Definisi Kerja}

Kerja adalah bagian sentral di dalam kehidupan. Dengan pemikiran dan tubuhnya, manusia mengorganisir pekerjaan membuat benda-benda yang dapat membantu pekerjaannya tersebut, dan menentukan tujuan akhir dari pekerjaannya.

Menurut Taliziduhu Ndraha dalam Lijan Poltak Sinambela (2016:335) kerja adalah suatu aktifitas yang dilakukan seseorang untuk memperoleh nilai positif dari aktifitas tersebut.

\section{c. Definisi Kepuasan Kerja}

Menurut Robbins dalam Sudaryo, Aribowo, dan Sofiati (2018:76) kepuasan kerja adalah sikap umum terhadap pekerjaan seseorang yang menunjukkan perbedaan antara jumlah penghargaan yang diterima pekerja dan jumlah yang mereka yakini seharusnya mereka terima.

\section{d. Dimensi dan Indikator}

Adapun dimensi dan indikator kepuasan kerja menurut Robbins dalam Muhammad Busro (2018:112) sebagai berikut:

a. Hubungan Kerja

Ditandai dengan keharmonisan dalam berinteraksi dengan atasan, komunikasi dua arah, kerjasama antar karyawan. Semakin lancar komunikasi yang terjadi dalam perusahaan, semakin tinggi pula tingkat kepuasan kerja yang dirasakan oleh karyawan.

Indikator dalam dimensi hubungan kerja sebagai berikut:

1) Keharmonisan dalam berinteraksi dengan atasan

Menciptakan hubungan baik dengan atasan ketika mendapatkan kesusahan maka dapat berkonsultasi atau meminta masukan kepada atasan.

2) Komunikasi dua arah

Semakin lancar komunikasi interpersonal yang terjadi di dalam perusahaan, maka semakin tinggi pula tingkat kepuasan yang akan dirasakan oleh karyawan.

3) Keterbukaan dan transparasi

Perusahaan harus mau membuka diri menerima ide dan pendapat dari karyawan mengenai penerapan hal tertentu sehingga membuat kaeryawan merasa dihargai.

b. Tantangan Kerja

Adanya kemauan untuk menyelesaikan tugas. Semakin besar tantangan kerja yang dihadapi oleh karyawan apabila mampu menyelesaikan dengan baik, maka tingkat kepuasan mereka semakin tinggi. Dengan demikian, pimpinan harus mampu memberikan tugas dan tanggung jawab yang sesuai dengan kapasitas karyawan.

Indikator dalam dimensi tantangan kerja adalah sebagai berikut: 
1) Menyelesaikan tugas

Menyelesaikan tugas dengan waktu yang telah ditentukan akan meningkatkan kepuasan kerja terhadap karyawan.

2) Kepuasan dalam menyelesaikan tugas

Dengan menyelesaikan tugas yang sulit maka karyawan akan mendapatkan kepuasan dalam menyelesaikan tugas.

3) Keterampilan dalam mengambil keputusan

Ketika melibatkan karyawan dalam proses pengambilan keputusan seperti tujuan yang dibutuhkan untuk mendukung pekerjaan.

c. Perlindungan Kerja

Adanya perlindungan dari pemerintah dalam bentuk peraturan perundang-undangan, perlindungan dari tempat bekerja dalam bentuk perjanjian kerja, perlindungan dari asuransi dalam bentuk jaminan asuransi bila terjadi sakit atau musibah lainnya.

Indikator dalam dimensi perlindungan kerja adalah sebagai berikut:

1) Perlindungan dari pemerintah

Pemerintah harus punya andil dalam melindungi hak-hak para pekerja dengan membuat peraturan yang dapat membuat pekerja merasa aman dalam bekerja.

2) Perlindungan dari perjanjian kerja

Dengan perlindungan dari perjanjian kerja yang telah di sepakati baik oleh perusahaan maupun oleh karyawan itu sendiri sehingga dapat bekerja dengan aman dan nyaman.

3) Perlindungan dari asuransi

Dengan memiliki asuransi maka kayawan telah melakukan proteksi atas segala resiko yang akan dihadapi nanti sehingga dapat melindungi diri mengambil alih kerugian yang dialami.

\section{Kepemimpinan}

\section{a. Definisi Kepemimpinan}

Menurut Yukl dalam Sudaryo, Aribowo, dan Sofiati (2018:148) mendefinisikan kepemimpinaan orang lain untuk memahami dan setuju apa yang harus dilakukan, bagaimana, kapan, dan di mana melakukannya. Selain itu juga meliputi memberikan kemudahan, inspirasi, motivasi, dan mengarahkan aktivitas (baik secara individu maupun kelompok) ke arah pencapaian tujuan organisasi.

\section{b. Dimensi dan Indikator}

Penelitian Fiedler dalam Robbins (2016:132) mengungkapkan tiga dimensi yang menentukan faktor-faktor kunci situasional terhadap efektivitas pemimpin yaitu:

a. Hubungan Pemimpin-Anggota

Dijabarkan menjadi indikator-indikator:

1) Tingkat keyakinan diri

2) Kepercayaan diri

3) Rasa hormat

b. Struktur Tugas

Dijabarkan menjadi indikator-indikator:

1) Instruksi tugas pekerjaan

2) Formulasi tugas pekerjaan

c. Kekuatan Posisi

Dijabarkan menjadi indikator-indikator:

1) Pemecatan

2) Pendisiplinan

3)

3. Komunikasi

a. Definisi Komunikasi 
Menurut Wibowo (2017:166) Komunikasi adalah proses penyampaian informasi dari satu pihak baik individu, kelompok atau organisasi sebagai sender kepada pihak lain sebagai receiver untuk memahami dan terbuka peluang memberikan respon baik kepada sender.

\section{b. Dimensi dan Indikator}

Menurut Pandi Afandi (2016:50) dimensi yang digunakan untuk mengukur komunikasi dalam organisasi yaitu:

a. Penyampaian Tugas

Jika seseorang manajer memiliki kemampuan berkomunikasi yang baik, maka dia dapat melakukan koordinasi dengan semua anggota timnya dengan baik. Seorang pemimpin harus mampu untuk memberikan instruksi yang jelas kepada seluruh karyawannya. Instruksi tersebut harus benar-benar dipahami oleh mereka, sehingga anak buah Anda itu bisa melakukan semua tugasnya dengan baik dan benar. Berikut indikator dalam penyampaian tugas agar diterima dengan tepat:

1) Bijaksana

Kebijaksanaan dalam komunikasi merupakan salah satu faktor yang mempengaruhi proses penyampaian informasi khususnya dalam dunia kerja. Sehingga dengan komunikasi yang bijak dapat saling menghargai baik sesame rekan kerja ataupun antar karyawan dengan atasannya.

2) Kesopanan

Kesantunan memang amat penting di mana pun individu berada. Dalam dunia bisnis, kesantunan berbahasa sangat mempengaruhi keberhasilan suatu bisnis dalam mengirim dan menerima informasi.

3) Kata yang tepat

Salah satu hal dalam komunikasi utama adalah pemilihan kata-kata agar keterbukaan tak saling menyakiti. Pikirkanlah dulu baik-baik sebelum mengucapkan sesuatu, sebab dampaknya bisa kemana-mana.

b. Umpan Balik

Umpan balik merupakan anggapan atau respon terhadap suatu pesan. Feedback yang ditumbulkan dari proses komunikasi memberikan gambaran kepada komunikator tentang hasil komunikasi yang dilakukannya. Berikut indikator dari umpan balik, yaitu:

1) Penerimaan tanggapan dari pesan yang disampaikan

Kejelasan pengiriman dan penerimaan pesan sangat berpengaruh terhadap kesinambungan komunikasi baik sesame rekan kerja maupun dengan atasan.

2) Penerimaan tanggapan dari penerimaan tugas

Penerimaan tanggapan dari penerimaan tugas sangat penting untuk diperhatikan oleh karyawan, sebab dengan adanya tanggapan berarti karyawan memahami maksud yang disampaikan dan diharapkan oleh organisasi.

3) Penerimaan kepastian tugas

Penerimaan kepastian tugas yang diberikan pemimpin kepada karyawan dapat mempermudah karyawan dalam menyelesaikan pekerjaan dengan cepat dan tepat.

\section{Kompetensi}

a. Definisi Kompetensi

Menurut Wibowo dalam Sudaryo, Aribowo, dan Sofiati (2018:180) memberikan definisi kompetensi sebagai suatu kemampuan untuk melaksanakan atau melakukan suatu pekerjaan atau tugas yang dilandasi atas keterampilan dan pengetahuan, serta didukung oleh sikap kerja yang dituntut oleh pekerjaan tersebut.

\section{b. Dimensi dan Indikator}


H1 Menurut Sudaryo, Aribowo, dan Sofiati (2018:191) Kompetensi diperoleh 4 dimensi kajian, yaitu:

a. Dimensi Karakter Pribadi (traits)

Dijabarkan menjadi indikator-indikator:

1) Watak

2) Sifat

3) Sikap

b. Dimensi Konsep diri (self-concept)

Dijabarkan menjadi indikator-indikator:

1) Penampilan

2) Tutur bahasan

3) Perilaku

c. Dimensi Pengetahuan (knowledge)

Dijabarkan menjadi indikator-indikator:

1) Pengetahuan tentang prosedur pelayanan

2) Pengetahuan tentang teknis pelayanan

d. Dimensi Keterampilan (skill)

Dijabarkan menjadi indikator-indikator:

1) Keterampilan administrative

2) Keterampilan manajerial

3) Keterampilan teknis

4) Keterampilan social

\section{Kerangka Pemikiran Teoritis}

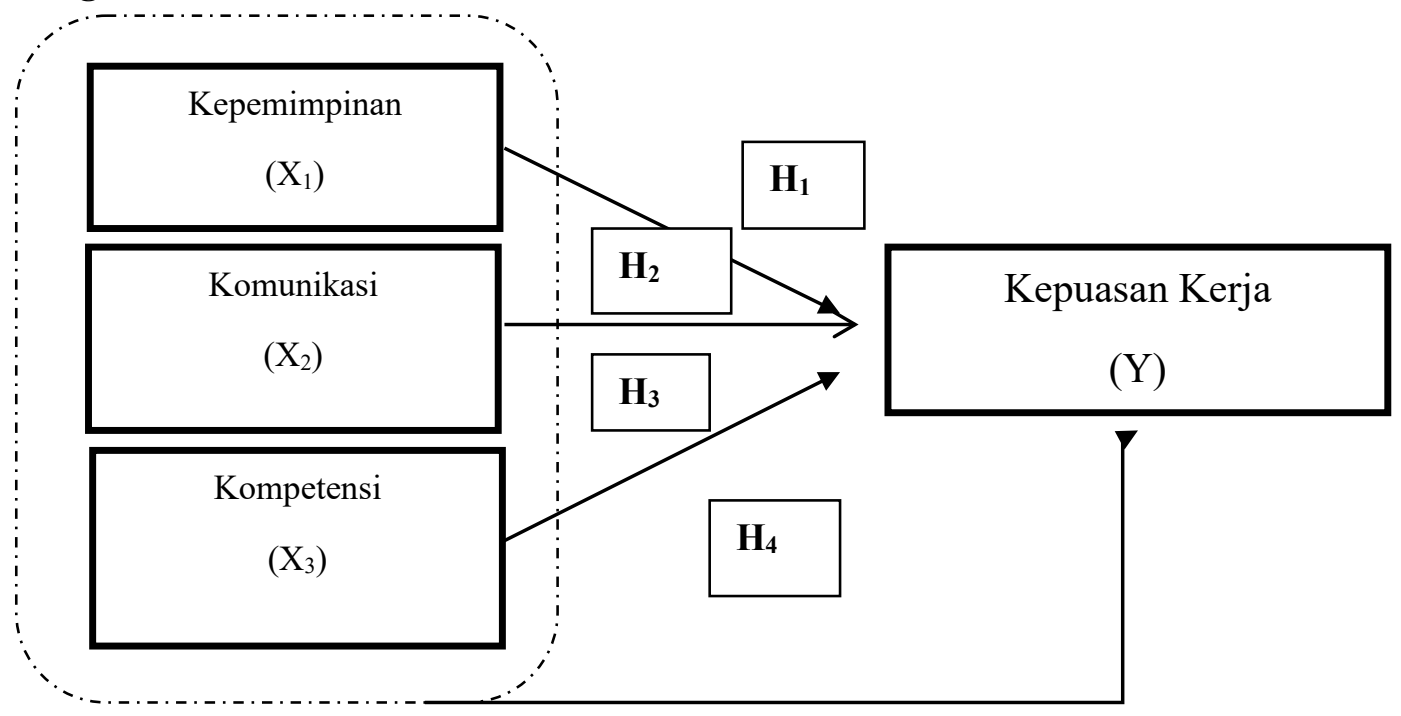

\section{Hipotesis}

$\mathrm{H}_{1}$ : Kepemimpinan berpengaruh terhadap Kepuasan Kerja Karyawan SMK Muhammadiyah 4 Jakarta.

$\mathrm{H}_{2}$ : Komunikasi berpengaruh terhadap Kepuasan Kerja Karyawan SMK Muhammadiyah 4.

$\mathrm{H}_{3}$ : Kompetensi berpengaruh terhadap Kepuasan Kerja Karyawan SMK Muhammadiyah 4.

$\mathrm{H}_{4}$ : Kepemimpinan, Komunikasi, dan Kompetensi berpengaruh terhadap Kepuasan Kerja Karyawan SMK Muhammadiyah 4. 


\section{B. Metodologi Penelitian}

\section{Teknik Pengumpulan Sampel}

a. Populasi

Metode pengampilan sampel adalah teknik untuk menentukan sampel yang akan digunakan dalam penelitian. Sampel merupakan bagian dari populasi yang dibutuhkan oleh peneliti untuk melakukan penelitian. Teknik pengambilan sampel yang digunakan dalam penelitian ini adalah nonprobability sampling dimana semua anggota populasi dijadikan sampel. Adapun metode yang digunakan dalam menentukan jumlah sampel dalam penelitian ini, yaitu metode sampel jenuh. Metode sampel jenuh adalah teknik penentuan sampel bila semua anggota populasi digunakan menjadi sampel dalam penelitian ini sebanyak 50 sampel atau karyawan.

\section{Analisis Hasil dan Pembahasan}

\section{Uji Kelayakan Instrumen}

\section{a. Uji Validitas}

uji validitas bertujuan untuk mengetahui seberapa cermat suatu item yang dapat mengukur apa yang diukur (kuesioner), dalam hal ini peneliti menggunakan korelasi pearson, yaitu cara dasar pengambilan keputusan pada uji validitas dalam penelitian ini sebagai berikut:

- Jika $r_{\text {hitung }}>\mathrm{r}_{\text {tabel, }}$, maka dinyatakan valid.

- Jika $\mathrm{r}_{\text {hitung }}<\mathrm{r}_{\text {tabel, }}$, makan dinyatakan tidak valid.

Tabel data hasil uji validitas yang valid dan tidak valid adalah sebagai berikut:

\begin{tabular}{|c|c|c|c|c|}
\hline Kode Item & $\mathrm{r}_{\text {hitung }}$ & Kondisi & $\mathrm{r}_{\text {tabel }}$ & Kriteria \\
\hline Y1 & 0,378 & $>$ & 0,361 & Valid \\
\hline Y2 & 0,457 & $>$ & 0,361 & Valid \\
\hline Y3 & 0,914 & $>$ & 0,361 & Valid \\
\hline Y4 & 0,669 & $>$ & 0,361 & Valid \\
\hline Y5 & 0,901 & $>$ & 0,361 & Valid \\
\hline Y6 & 0,592 & $>$ & 0,361 & Valid \\
\hline Y7 & 0,901 & $>$ & 0,361 & Valid \\
\hline Y8 & 0,901 & $>$ & 0,361 & Valid \\
\hline Y9 & 0,592 & $>$ & 0,361 & Valid \\
\hline Y10 & 0,668 & $>$ & 0,361 & Valid \\
\hline Y11 & 0,901 & $>$ & 0,361 & Valid \\
\hline Y12 & 0,592 & $>$ & 0,361 & Valid \\
\hline Y13 & 0,668 & $>$ & 0,361 & Valid \\
\hline Y14 & 0,668 & $>$ & 0,361 & Valid \\
\hline Y15 & 0,393 & $>$ & 0,361 & Valid \\
\hline Y16 & 0,901 & $>$ & 0,361 & Valid \\
\hline Y17 & 0,901 & $>$ & 0,361 & Valid \\
\hline Y18 & 0,668 & $>$ & 0,361 & Valid \\
\hline Y19 & 0,901 & $>$ & 0,361 & Valid \\
\hline Y20 & 0,592 & $>$ & 0,361 & Valid \\
\hline Y21 & 0,668 & $>$ & 0,361 & Valid \\
\hline Y22 & 0,901 & $>$ & 0,361 & Valid \\
\hline Y23 & 0,668 & $>$ & 0,361 & Valid \\
\hline Y24 & 0,901 & $>$ & 0,361 & Valid \\
\hline & & & & \\
\hline
\end{tabular}




\begin{tabular}{|c|c|c|c|c|}
\hline Kode Item & $\mathrm{r}_{\text {hitung }}$ & Kondisi & $\mathrm{r}_{\text {tabel }}$ & Kriteria \\
\hline $\mathrm{X}_{1.1}$ & 0,334 & $<$ & 0,361 & Tidak Valid \\
\hline $\mathrm{X}_{1.2}$ & 0,847 & $>$ & 0,361 & Valid \\
\hline $\mathrm{X}_{1.3}$ & 0,741 & $>$ & 0,361 & Valid \\
\hline $\mathrm{X}_{1.4}$ & 0,532 & $>$ & 0,361 & Valid \\
\hline $\mathrm{X}_{1.5}$ & 0,772 & $>$ & 0,361 & Valid \\
\hline $\mathrm{X}_{1.6}$ & 0,840 & $>$ & 0,361 & Valid \\
\hline $\mathrm{X}_{1.7}$ & 0,772 & $>$ & 0,361 & Valid \\
\hline $\mathrm{X}_{1.8}$ & 0,528 & $>$ & 0,361 & Valid \\
\hline $\mathrm{X}_{1.9}$ & 0,515 & $>$ & 0,361 & Valid \\
\hline $\mathrm{X}_{1.10}$ & 0,840 & $>$ & 0,361 & Valid \\
\hline $\mathrm{X}_{1.11}$ & 0,741 & $>$ & 0,361 & Valid \\
\hline $\mathrm{X}_{1.12}$ & 0,840 & $>$ & 0,361 & Valid \\
\hline $\mathrm{X}_{1.13}$ & 0,532 & $>$ & 0,361 & Valid \\
\hline $\mathrm{X}_{1.14}$ & 0,532 & $>$ & 0,361 & Valid \\
\hline $\mathrm{X}_{1.15}$ & 0,772 & $>$ & 0,361 & Valid \\
\hline $\mathrm{X}_{1.16}$ & 0,840 & $>$ & 0,361 & Valid \\
\hline $\mathrm{X}_{1.1} 17$ & 0,772 & $>$ & 0,361 & Valid \\
\hline $\mathrm{X}_{1.18} 18$ & 0,840 & $>$ & 0,361 & Valid \\
\hline $\mathrm{X}_{1.19} 19$ & 0,772 & $>$ & 0,361 & Valid \\
\hline $\mathrm{X}_{1.2} 20$ & 0,840 & $>$ & 0,361 & Valid \\
\hline $\mathrm{X}_{1.21} 1$ & 0,772 & $>$ & 0,361 & Valid \\
\hline & & & & \\
\hline
\end{tabular}

\begin{tabular}{|c|c|c|c|c|}
\hline Kode Item & $\mathrm{r}_{\text {hitung }}$ & Kondisi & $\mathrm{r}_{\text {tabel }}$ & Kriteria \\
\hline $\mathrm{X}_{2} \cdot 1$ & 0,720 & $>$ & 0,361 & Valid \\
\hline $\mathrm{X}_{2} \cdot 2$ & 0,491 & $>$ & 0,361 & Valid \\
\hline $\mathrm{X}_{2} \cdot 3$ & 0,698 & $>$ & 0,361 & Valid \\
\hline $\mathrm{X}_{2} \cdot 4$ & 0,698 & $>$ & 0,361 & Valid \\
\hline $\mathrm{X}_{2} \cdot 5$ & 0,436 & $>$ & 0,361 & Valid \\
\hline $\mathrm{X}_{2} \cdot 6$ & 0,720 & $>$ & 0,361 & Valid \\
\hline $\mathrm{X}_{2} \cdot 7$ & 0,698 & $>$ & 0,361 & Valid \\
\hline $\mathrm{X}_{2} \cdot 8$ & 0,600 & $>$ & 0,361 & Valid \\
\hline $\mathrm{X}_{2} \cdot 9$ & 0,698 & $>$ & 0,361 & Valid \\
\hline $\mathrm{X}_{2} \cdot 10$ & 0,638 & $>$ & 0,361 & Valid \\
\hline $\mathrm{X}_{2} \cdot 11$ & 0,600 & $>$ & 0,361 & Valid \\
\hline $\mathrm{X}_{2} \cdot 12$ & 0,698 & $>$ & 0,361 & Valid \\
\hline $\mathrm{X}_{2} \cdot 13$ & 0,336 & $<$ & 0,361 & Tidak Valid \\
\hline $\mathrm{X}_{2} \cdot 14$ & 0,638 & $>$ & 0,361 & Valid \\
\hline $\mathrm{X}_{2} \cdot 15$ & 0,600 & $>$ & 0,361 & Valid \\
\hline $\mathrm{X}_{2} \cdot 16$ & 0,542 & $>$ & 0,361 & Valid \\
\hline $\mathrm{X}_{2} \cdot 17$ & 0,720 & $>$ & 0,361 & Valid \\
\hline $\mathrm{X}_{2} \cdot 18$ & 0,698 & $>$ & 0,361 & Valid \\
\hline
\end{tabular}




\begin{tabular}{|c|c|c|c|c|}
\hline Kode Item & $\mathrm{r}_{\text {hitung }}$ & Kondisi & $\mathrm{r}_{\text {tabel }}$ & Kriteria \\
\hline $\mathrm{X}_{3.1}$ & 0,696 & $>$ & 0,361 & Valid \\
\hline $\mathrm{X}_{3.2}$ & 0,687 & $>$ & 0,361 & Valid \\
\hline $\mathrm{X}_{3.3}$ & 0,500 & $>$ & 0,361 & Valid \\
\hline$X_{3.4}$ & 0,696 & $>$ & 0,361 & Valid \\
\hline$X_{3.5}$ & 0,696 & $>$ & 0,361 & Valid \\
\hline $\mathrm{X}_{3.6}$ & 0,472 & $>$ & 0,361 & Valid \\
\hline $\mathrm{X}_{3.7}$ & 0,783 & $>$ & 0,361 & Valid \\
\hline $\mathrm{X}_{3.8}$ & 0,696 & $>$ & 0,361 & Valid \\
\hline $\mathrm{X}_{3.9}$ & 0,592 & $>$ & 0,361 & Valid \\
\hline $\mathrm{X}_{3.10}$ & 0,665 & $>$ & 0,361 & Valid \\
\hline $\mathrm{X}_{3.11}$ & 0,723 & $>$ & 0,361 & Valid \\
\hline $\mathrm{X}_{3.12}$ & 0,642 & $>$ & 0,361 & Valid \\
\hline $\mathrm{X}_{3.13}$ & 0,731 & $>$ & 0,361 & Valid \\
\hline $\mathrm{X}_{3.14}$ & 0,592 & $>$ & 0,361 & Valid \\
\hline $\mathrm{X}_{3.15}$ & 0,696 & $>$ & 0,361 & Valid \\
\hline$X_{3.16}$ & 0,731 & $>$ & 0,361 & Valid \\
\hline $\mathrm{X}_{3.17}$ & 0,696 & $>$ & 0,361 & Valid \\
\hline $\mathrm{X}_{3.18}$ & 0,472 & $>$ & 0,361 & Valid \\
\hline $\mathrm{X}_{3 .} .19$ & 0,696 & $>$ & 0,361 & Valid \\
\hline$X_{3.20}$ & 0,731 & $>$ & 0,361 & Valid \\
\hline$X_{3.21}$ & 0,472 & $>$ & 0,361 & Valid \\
\hline $\mathrm{X}_{3} .22$ & 0,731 & $>$ & 0,361 & Valid \\
\hline$X_{3.23}$ & 0,696 & $>$ & 0,361 & Valid \\
\hline $\mathrm{X}_{3.24}$ & 0,731 & $>$ & 0,361 & Valid \\
\hline$X_{3} .25$ & 0,413 & $>$ & 0,361 & Valid \\
\hline $\mathrm{X}_{3.26}$ & 0,731 & $>$ & 0,361 & Valid \\
\hline$X_{3} .27$ & 0,724 & $>$ & 0,361 & Valid \\
\hline $\mathrm{X}_{3.28}$ & 0,696 & $>$ & 0,361 & Valid \\
\hline $\mathrm{X}_{3.29}$ & 0,731 & $>$ & 0,361 & Valid \\
\hline$X_{3 .} .30$ & 0,696 & $>$ & 0,361 & Valid \\
\hline $\mathrm{X}_{3.31}$ & 0,696 & $>$ & 0,361 & Valid \\
\hline$X_{3.32}$ & 0,592 & $>$ & 0,361 & Valid \\
\hline $\mathrm{X}_{3} .33$ & 0,724 & $>$ & 0,361 & Valid \\
\hline $\mathrm{X}_{3.34}$ & 0,731 & $>$ & 0,361 & Valid \\
\hline $\mathrm{X}_{3.35}$ & 0,724 & $>$ & 0,361 & Valid \\
\hline$X_{3} .36$ & 0,696 & $>$ & 0,361 & Valid \\
\hline$X_{3.37}$ & 0,696 & $>$ & 0,361 & Valid \\
\hline $\mathrm{X}_{3.38}$ & 0,618 & $>$ & 0,361 & Valid \\
\hline$X_{3.39}$ & 0,592 & $>$ & 0,361 & Valid \\
\hline $\mathrm{X}_{3.40}$ & 0,473 & $>$ & 0,361 & Valid \\
\hline $\mathrm{X}_{3.41}$ & 0,472 & $>$ & 0,361 & Valid \\
\hline $\mathrm{X}_{3 .} .42$ & 0,724 & $>$ & 0,361 & Valid \\
\hline $\mathrm{X}_{3.43}$ & 0,724 & $>$ & 0,361 & Valid \\
\hline $\mathrm{X}_{3 .} .44$ & 0,472 & $>$ & 0,361 & Valid \\
\hline $\mathrm{X}_{3 .} .45$ & 0,269 & $<$ & 0,361 & Tidak Valid \\
\hline
\end{tabular}

\section{b. Uji Realibilitas}


Merupakan suatu pengukuran yang menunjukan sejauh mana pengukuran tersebut tanpa bias (bebas kesalahan). Rumus Cronbanch's alpha dapat digunakan untuk mencari reliabilitas yang skornya merupakan rentangan antara beberapa nilai atau bentuk skala. Untuk uji reliabilitas jika hasil Cronbanch's alpha> 0,60, maka dapat dikatakan reliable.

Dasar pengambilan keputusan :

- Jika $r$ alpha positif dan $r$ alpha $>0,60$, maka butir atau variabel tersebut reliable.

- Jika $r$ alpha positif dan $r$ alpha $<0,60$, maka butir atau variabel tersebut tidak reliable.

- Jika $\mathrm{r}$ alpha $>0,60$ tapi bertanda negatif, maka butir atau variabel tersebut tidak reliable.

\begin{tabular}{|c|c|c|c|c|}
\hline Variabel & N of Item & $\begin{array}{c}\text { Cronbanch's } \\
\text { alpha }\end{array}$ & Batas Nilai & Keterangan \\
\hline Kepuasan Kerja & 24 & 0,959 & 0,60 & Reliabel \\
\hline Kepemimpinan & 21 & 0,950 & 0,60 & Reliabel \\
\hline Komunikasi & 18 & 0,904 & 0,60 & Reliabel \\
\hline Kompetensi & 45 & 0,969 & 0,60 & Reliabel \\
\hline
\end{tabular}

\section{Uji Normalitas Residual}

Uji normalitas juga dapat menggunakan metode Kolmogorov-Smirnov Tes dengan non parametrik statistic. Kaidah pengujian berdasarkan nilai probability:

a. Jika Probabilitas (sig) $>0,05$ maka $\mathrm{H}_{\mathrm{o}}$ diterima data terdistribusi normal.

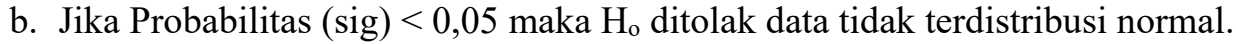

Uji normalitas dengan metode Kolmogorov-Smirnov Tes dalam penelitian ini menggunakan residual unstandardized.

Berikut hasil output uji normalitas dengan metode Kolmogorov-Smirnov Tes:

One-Sample Kolmogorov-Smirnov Test

\begin{tabular}{|ll|r|}
\hline & & $\begin{array}{c}\text { Unstandardized } \\
\text { Residual }\end{array}$ \\
\hline $\mathrm{N}$ & Mean & 50 \\
& Std. & .0000000 \\
& Deviation & 6.41844674 \\
Most Extreme Differences & Absolute & .091 \\
& Positive & .091 \\
Test Statistic & Negative & -.062 \\
Asymp. Sig. (2-tailed) & & .091 \\
& & $.200^{\mathrm{c}, \mathrm{d}}$ \\
\hline
\end{tabular}
a. Test distribution is Normal.
b. Calculated from data.
c. Lilliefors Significance Correction.
$\mathrm{d}$. This is a lower bound of the true significance.

\section{Uji Analisis Statistik Deskriptif}

\section{a. Uji Deskriptif}


Statistik deskriptif dimaksudkan untuk mengenali pola data dan merangkum informasi yang terdapat dalam data. Berikut tabel 4.5 yang menyajikan statistik deskriptif yang terdiri dari min, max, mean, dan standart devination .

\section{Descriptive Statistics}

\begin{tabular}{|l|r|r|r|r|r|}
\hline & N & Minimum & Maximum & Mean & $\begin{array}{c}\text { Std. } \\
\text { Deviation }\end{array}$ \\
\hline X1 & 50 & 57 & 100 & 87.64 & 11.742 \\
X2 & 50 & 68 & 85 & 75.82 & 5.476 \\
X3 & 50 & 119 & 215 & 185.36 & 22.519 \\
Y & 50 & 96 & 120 & 108.80 & 8.177 \\
Valid N & 50 & & & & \\
(listwise) & & & & \\
\hline
\end{tabular}

b.

Uji Multikolonieritas

Uji multikolonieritas bertujuan untuk menguji pada model regresi yang ditemukan adanya korelasi atau hubungan yang signifikan antar variabel bebas dimana dalam model regresi yang baik seharusnya tidak terjadi korelasi diantara variabel bebas. Pengambilan keputusan dalam uji multikolonieritas adalah dengan melihat nilai Tolerance dan VIF (Variance Inflation Factor) yakni sebagai berikut:

a. nilai Tolerance $>0,10$

b.

$\mathrm{VIF}<10$
Tidak terjadi multikolonieritas, jika

Tidak terjadi multikolonieritas, jika

c.

Uji Multikolonieritas

\section{Coefficients $^{\mathrm{a}}$}

\begin{tabular}{|c|c|c|c|c|c|c|c|}
\hline \multirow[b]{2}{*}{ Model } & \multicolumn{2}{|c|}{$\begin{array}{l}\text { Unstandardized } \\
\text { Coefficients }\end{array}$} & \multirow{2}{*}{$\begin{array}{c}\text { Standardized } \\
\text { Coefficients } \\
\text { Beta } \\
\end{array}$} & \multirow[b]{2}{*}{$\mathrm{T}$} & \multirow[b]{2}{*}{ Sig. } & \multicolumn{2}{|c|}{$\begin{array}{l}\text { Collinearity } \\
\text { Statistics }\end{array}$} \\
\hline & B & $\begin{array}{l}\text { Std. } \\
\text { Error }\end{array}$ & & & & Tolerance & VIF \\
\hline $1 \quad$ (Constant) & 27.610 & 16.361 & & 1.688 & .098 & & \\
\hline Kepemimpinan(X1) & .185 & .084 & .265 & 2.193 & .033 & .916 & 1.092 \\
\hline Komunikasi(X2) & .730 & .180 & .489 & 4.057 & .000 & .923 & 1.083 \\
\hline Kompetensi(X3) & .052 & .043 & .144 & 1.213 & .231 & .953 & 1.049 \\
\hline
\end{tabular}

\section{c. Uji Heterokedastisitas}

Uji heterokedastisitas yaitu untuk menguji apakah dalam model regresi terjadi ketidaksamaan variance dari residual satu pengamatan ke pengamatan yang lain. Dasar kriteria pengambilan keputusan, jika ada pola tertentu titik-titik yang ada membentuk suatu pola tertentu (bergelombang, melebar, kemudian menyempit), maka terjadi heterokedastisitas. Jika tidak ada pola yang jelas, seperti titik-titik menyebar di atas dan di bawah angka 0 pada sumbu Y, maka tidak terjadi heterokedastisitas (Priyatno, 2014:113). 
Uji heterokedastisitas dengan menggunakan Uji Scatterplot yang dibantu menggunakan program SPSS versi 22. Hasil dari Uji Heterokedastisitas dalam penelitian ini adalah sebagai berikut:

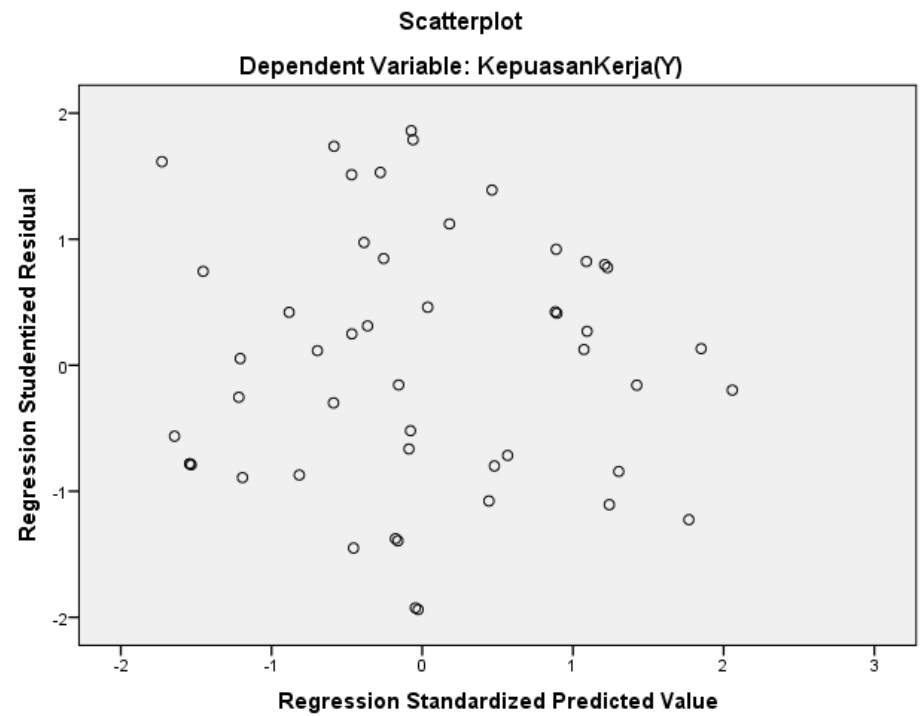

\section{d. Uji Autokorelasi}

Autokorelasi merupakan korelasi antara anggota observasi yang disusun menurut waktu dan tempat. Model regresi yang baik seharusnya tidak terjadi autokorelasi. Metode pengujian menggunakan uji Durbin Watson (DW Test). Dasar pengambilan keputusan pada uji Durbin Watson sebagai berikut:

1. DU $<$ DW $<4$-DU maka Ho diterima, artinya tidak terjadi autokorelasi.

2. $\mathrm{DW}<\mathrm{DL}$ atau $\mathrm{DW}>4$-DL maka Ho ditolak, artinya terjadi autokorelasi.

3. DL $<$ DW $<$ DU atau 4-DU $<$ DW $<4$-DL. artinya tidak ada kepastian atau kesimpulan yang pasti.

\begin{tabular}{|l|r|r|r|r|r|}
\multicolumn{7}{|c|}{ Model Summary } \\
\hline Model & \multicolumn{1}{c|}{ R } & R Square & $\begin{array}{r}\text { Adjusted } \\
\text { R Square }\end{array}$ & $\begin{array}{c}\text { Std. Error } \\
\text { of the } \\
\text { Estimate }\end{array}$ & $\begin{array}{c}\text { Durbin- } \\
\text { Watson }\end{array}$ \\
\hline 1 & $.620^{\mathrm{a}}$ & .384 & .344 & 6.624 & 1.061 \\
\hline
\end{tabular}

a. Predictors: (Constant), Kompetensi(X3), Komunikasi(X2),

Kepemimpinan(X1)

b. Dependent Variable: KepuasanKerja(Y)

\section{e. Uji Korelasi}

Analisis korelasi adalah hubungan antara dua variabel. Dalam perhitungan korelasi akan didapat koefisien korelasi yang menunjukkan keeratan hubungan antar dua variabel tersebut.

a. Nilai koefisien korelasi berkisar antara 0 sampai 1 atau 0 sampai -1 , nilai semakin mendekati 1 atau -1 , maka hubungan semakin erat.

b. Nilai koefisien korelasi mendekati 0 maka hubungan semakin lemah. 


\section{Correlations}

\begin{tabular}{|c|c|c|c|c|c|}
\hline & & Kepuasankerja & Kepemimpinan & komunikasi & kompetensi \\
\hline Kepuasankerja & $\begin{array}{l}\text { Pearson } \\
\text { Correlation } \\
\text { Sig. }(2- \\
\text { tailed) } \\
\mathrm{N}\end{array}$ & 50 & $\begin{array}{l}.399^{* *} \\
.004 \\
50\end{array}$ & $\begin{array}{l}.532^{* *} \\
.000 \\
50\end{array}$ & $\begin{array}{l}.124 \\
.390 \\
50\end{array}$ \\
\hline Kepemimpinan & $\begin{array}{l}\text { Pearson } \\
\text { Correlation } \\
\text { Sig. (2- } \\
\text { tailed) } \\
\text { N }\end{array}$ & $\begin{array}{l}.399^{* *} \\
.004 \\
50\end{array}$ & 1 & $\begin{array}{l}.230 \\
.109 \\
50\end{array}$ & $\begin{array}{l}.148 \\
.307 \\
50\end{array}$ \\
\hline komunikasi & $\begin{array}{l}\text { Pearson } \\
\text { Correlation } \\
\text { Sig. (2- } \\
\text { tailed) } \\
\text { N }\end{array}$ & $\begin{array}{l}.532^{* *} \\
.000 \\
50\end{array}$ & $\begin{array}{l}.230 \\
.109 \\
50\end{array}$ & 50 & $\begin{array}{l}-.120 \\
.407 \\
50\end{array}$ \\
\hline kompetensi & $\begin{array}{l}\text { Pearson } \\
\text { Correlation } \\
\text { Sig. (2- } \\
\text { tailed) } \\
\text { N }\end{array}$ & $\begin{array}{l}.124 \\
.390 \\
50\end{array}$ & $\begin{array}{l}.148 \\
.307 \\
50\end{array}$ & $\begin{array}{l}-.120 \\
.407 \\
50\end{array}$ & 50 \\
\hline
\end{tabular}

**. Correlation is significant at the 0.01 level (2-tailed).

a. Korelasi antara Kepemimpinan $\left(\mathrm{X}_{1}\right)$ dengan Kepuasan Kerja (Y) sebesar 0,399 mendekati 0 dengan signifikansi $0,004<0,05$ menunjukkan Kepemimpinan $\left(\mathrm{X}_{1}\right)$ memiliki korelasi yang cukup rendah terhadap Kepuasan Kerja (Y).

b. Korelasi antara Komunikasi $\left(\mathrm{X}_{2}\right)$ dengan Kepuasan Kerja (Y) sebesar 0,532 mendekati 0 dengan signifikansi $0,000<0,05$ menunjukkan Komunikasi $\left(\mathrm{X}_{2}\right)$ memiliki korelasi yang cukup sedang terhadap Kepuasan Kerja (Y).

c. Korelasi antara Kompetensi $\left(\mathrm{X}_{3}\right)$ dengan Kepuasan Kerja (Y) sebesar 0,124 mendekati 0 dengan signifikansi $0,390>0,05$ menunjukkan Kompetensi $\left(\mathrm{X}_{3}\right)$ memiliki korelasi yang sangat rendah terhadap Kepuasan Kerja (Y).

\section{f. Uji Regresi Linier Berganda}

Analisis Regresi Linier Berganda digunakan untuk menganalisis pengaruh Kepemimpinan $\left(\mathrm{X}_{1}\right)$, Komunikasi $\left(\mathrm{X}_{2}\right)$, dan Kompetensi $\left(\mathrm{X}_{3}\right)$ terhadap Kepuasan Kerja (Y)

\section{Coefficients $^{\mathrm{a}}$}

\begin{tabular}{|c|c|c|c|c|c|c|c|}
\hline \multirow[b]{2}{*}{ Model } & \multicolumn{2}{|c|}{$\begin{array}{c}\text { Unstandardized } \\
\text { Coefficients }\end{array}$} & \multirow{2}{*}{$\begin{array}{c}\text { Standardized } \\
\text { Coefficients } \\
\text { Beta }\end{array}$} & \multirow[b]{2}{*}{$\mathrm{T}$} & \multirow[b]{2}{*}{ Sig. } & \multicolumn{2}{|c|}{ Collinearity Statistics } \\
\hline & B & $\begin{array}{l}\text { Std. } \\
\text { Error }\end{array}$ & & & & Tolerance & VIF \\
\hline $1 \quad$ (Constant) & 27.610 & 16.361 & & 1.688 & .098 & & \\
\hline Kepemimpinan(X1) & .185 & .084 & .265 & 2.193 & .033 & .916 & 1.092 \\
\hline Komunikasi(X2) & .730 & .180 & .489 & 4.057 & .000 & .923 & 1.083 \\
\hline Kompetensi(X3) & .052 & .043 & .144 & 1.213 & .231 & .953 & 1.049 \\
\hline
\end{tabular}


a. Dependent Variable: KepuasanKerja(Y)

dapat diketahui bahwa persamaan regresi:

$\mathrm{Y}=27,610+0,185\left(\mathrm{X}_{1}\right)+0,730\left(\mathrm{X}_{2}\right)+0,052\left(\mathrm{X}_{3}\right)$

Dari hasil analisis dan persamaan regresi linier berganda, dapat diperoleh persamaan regresi sebagai berikut:

a. Nilai Konstanta adalah 27,610 yang artinya jika Kepemimpinan, Komunikasi, Kompetensi Terhadap Kepuasan Kerja nilainya 0, maka Kepuasan Kerja akan bernilai sebesar 27,610.

b. Koefisien Regresi Kepemimpinan $\left(\mathrm{X}_{1}\right)$ bersifat positif sebesar 0,185 yang artinya jika variabel kepemimpinan meningkat 1 satuan, maka akan meningkatkan Kepuasan Kerja sebesar 0,185 dengan asumsi variabel lain tetap.

c. Koefisien Regresi Komunikasi $\left(\mathrm{X}_{2}\right)$ bersifat positif sebesar 0,730 yang artinya jika variabel komunikasi meningkat 1 satuan, maka akan meningkatkan Kepuasan Kerja sebesar 0,730 dengan asumsi variabel lain tetap.

d. Koefisien Regresi Kompetensi $\left(\mathrm{X}_{3}\right)$ bersifat positif sebesar 0,052 yang artinya jika variabel Kompetensi meningkat 1 satuan, maka akan meningkatkan Kepuasan Kerja sebesar 0,052 dengan asumsi variabel lain tetap.

\section{Uji Hipotesis}

a. Uji F

Uji F menunjukkan semua variabel independen mempunyai pengaruh secara bersamasama terhadap variabel dependen. Kriteria pengujian keputusannya dengan tingkat signifikansi $(\alpha)=0,05$ adalah dengan membandingkan nilai $f$ hitung dengan $\mathrm{f}$ tabel yaitu:

a. Jika $\mathrm{F}_{\text {hitung }}>\mathrm{F}_{\text {tabel }} 2,81$ maka $\mathrm{H}_{\mathrm{o}}$ ditolak Ha diterima

b. Jika $\mathrm{F}_{\text {hitung }}<\mathrm{F}_{\text {tabel }} 2,81 \mathrm{H}_{\mathrm{o}}$ diterima dan Ha ditolak

Berdasarkan signifikansi:

a. Jika signifikansi $>0,05$ maka Ho diterima dan Ha ditolak

b. Jika signifikansi $<0,05$ maka Ho ditolak dan Ha diterima

Menentukan $\mathrm{f}$ tabel pada tingkat signifikansi 0,05 dengan df1 (jumlah variabel -1) atau 4$1=3$, dan df2 (n-k-1) atau 50-3-1=46, maka hasil $\mathrm{F}$ tabel $=2,81$

ANOVA ${ }^{\mathrm{a}}$

\begin{tabular}{|c|c|c|c|c|c|}
\hline Model & $\begin{array}{l}\text { Sum of } \\
\text { Squares }\end{array}$ & Df & $\begin{array}{l}\text { Mean } \\
\text { Square }\end{array}$ & $\mathrm{F}$ & Sig. \\
\hline 1 Regression & 1257.374 & 3 & 419.125 & 9.551 & $.000^{\mathrm{b}}$ \\
\hline Residual & 2018.626 & 46 & 43.883 & & \\
\hline Total & 3276.000 & 49 & & & \\
\hline
\end{tabular}

a. Dependent Variable: KepuasanKerja(Y)

b. Predictors: (Constant), Kompetensi(X3), Komunikasi(X2), Kepemimpinan(X1)

Diperoleh $\mathrm{F}_{\text {hitung }}$ sebesar 9,551 > nilai $\mathrm{F}_{\text {tabel }}$ 2,81 dan nilai probabilitas (signifikan) sebesar 0,000 karena nilai sig $0,000<0,05$. Maka $\mathrm{Ho}_{4}$ ditolak dan $\mathrm{H}_{44}$ diterima. Dengan demikian dapat disimpulkan bahwa terdapat pengaruh secara signifikan antara Kepemimpinan $\left(\mathrm{X}_{1}\right)$, Komunikasi $\left(\mathrm{X}_{2}\right)$, dan Kompetensi $\left(\mathrm{X}_{3}\right)$ terhadap Kepuasan Kerja (Y).

\section{b. Uji t}

Uji t pada dasarnya menunjukkan seberapa jauh pengaruh variabel independen secara individual terhadap variabel dependen. Cara melakukan uji $\mathrm{t}$ dengan tingkat signifikansi $(\alpha)=$ 0,05 adalah dengan membandingkan nilai t hitungnya dengan $t$ tabel yaitu: 
a. Jika $t_{\text {hitung }}>t_{\text {tabel }} 2,012$ maka Ho ditolak dan Ha diterima

b. Jika $t_{\text {hitung }}<t_{\text {tabel }} 2,012$ maka Ho diterima dan Ha ditolak

Berdasarkan signifikansi:

a. Jika signifikansi $>0,05$ maka Ho diterima dan Ha ditolak

b. Jika signifikansi $<0,05$ maka Ho ditolak dan Ha diterima

Menentukan $\mathrm{t}$ tabel dapat dilihat pada $\mathrm{t}$ tabel signifikansi 0,05 dengan derajat kebebasan $\mathrm{df}=\mathrm{n}-\mathrm{k}-1$ atau 50-3-1=46 adalah jumlah responden, maka didapat nilai $\mathrm{t}$ tabel $=2,012$

\section{Coefficients $^{\mathrm{a}}$}

\begin{tabular}{|c|c|c|c|c|c|}
\hline \multirow[b]{2}{*}{ Model } & \multicolumn{2}{|c|}{$\begin{array}{c}\text { Unstandardized } \\
\text { Coefficients }\end{array}$} & \multirow{2}{*}{$\begin{array}{c}\text { Standardized } \\
\text { Coefficients } \\
\text { Beta } \\
\end{array}$} & \multirow[b]{2}{*}{$\mathrm{T}$} & \multirow[b]{2}{*}{ Sig. } \\
\hline & $\mathrm{B}$ & $\begin{array}{l}\text { Std. } \\
\text { Error }\end{array}$ & & & \\
\hline $1 \quad$ (Constant) & 27.610 & 16.361 & & 1.688 & .098 \\
\hline Kepemimpinan(X1) & .185 & .084 & .265 & 2.193 & .033 \\
\hline Komunikasi(X2) & .730 & .180 & .489 & 4.057 & .000 \\
\hline Kompetensi(X3) & .052 & .043 & .144 & 1.213 & .231 \\
\hline
\end{tabular}

a. Dependent Variable: KepuasanKerja(Y)

Dijelaskan sebagai berikut:

1) Variabel kepemimpinan $\left(X_{1}\right)$ nilai $t$ hitung $>t$ tabel $(2,193>2,012)$ Ho ditolak dan nilai signifikansi $(0,033>0,05)$ maka Ha diterima, yang artinya kepemimpinan berpengaruh signifikan terhadap kepuasan kerja.

2) Variabel komunikasi $\left(\mathrm{X}_{2}\right)$ nilai $\mathrm{t}_{\text {hitung }}>\mathrm{t}$ tabel $(4,057>2,012)$ Ho ditolak dan nilai signifikansi $(0,000<0,05)$ maka Ha diterima, yang artinya komunikasi berpengaruh signifikansi terhadap kepuasan kerja.

3) Variabel kompetensi $\left(X_{3}\right)$ nilai $t_{\text {hitung }}<t_{\text {tabel }}(1,213<2,012)$ Ho diterima dan nilai signifikansi $(0,231>0,05)$ maka Ha ditolak, yang artinya kompetensi tidak berpengaruh signifikansi terhadap kepuasan kerja.

\section{c. Uji Koefisien Determinasi (R2)}

Koefisien determinasi pada intinya mengukur seberapa jauh kemampuan model dalam menerangkan variasi variabel dependen.

\begin{tabular}{|l|l|r|r|c|}
\multicolumn{1}{|c|}{ Model Summary $^{\mathbf{b}}$} \\
\hline Model & $\mathrm{R}$ & $\begin{array}{c}\mathrm{R} \\
\text { Square }\end{array}$ & $\begin{array}{c}\text { Adjusted R } \\
\text { Square }\end{array}$ & $\begin{array}{c}\text { Std. Error of the } \\
\text { Estimate }\end{array}$ \\
\hline 1 & $.620^{\mathrm{a}}$ & .384 & .344 & 6.624 \\
\hline
\end{tabular}

a. Predictors: (Constant), Kompetensi(X3), Komunikasi(X2),

Kepemimpinan(X1)

\section{b. Dependent Variable: KepuasanKerja(Y)}

Dapat dilihat bahwa nilai Adjusted $R$ Square sebesar 0,384 (38,4\%) artinya menunjukkan bahwa persentase sumbangan pengaruh variabel independent (kepemimpinan, komunikasi, dan kompetensi) terhadap variabel dependen (kepuasan kerja) adalah sebesar 38,4\% sedangkan sisanya sebesar $61,6 \% \quad(100 \%-38,4 \%=61,6 \%)$ dipengaruhi oleh variabel lain (disiplin kerja, lingkungan kerja, stress kerja dan lain-lain) yang tidak termasuk dalam penelitian ini. 


\section{Kesimpulan}

Berdasarkan hasil penelitian ini untuk menguji pengaruh variabel Kepemimpinan, Komunikasi, dan Kompetensi terhadap Kepuasan Kerja SMK Muhammadiyah 4 Jakarta memberikan kesimpulan dari peneliti sebagai berikut:

1. Pengaruh Kepemimpinan $\left(\mathrm{X}_{1}\right)$ terhadap Kepuasan Kerja $(\mathrm{Y})$ menunjukkan bahwa hasil uji t dari variabel Kepemimpinan $\mathrm{X}_{1}$ nilai $t_{\text {hitung }}>\mathrm{t}_{\text {tabel }}(2,193>2,012)$ Ho ditolak dan nilai signifikansi $(0,033>0,05)$ maka Ha diterima, yang artinya kepemimpinan berpengaruh signifikan terhadap kepuasan kerja.

Dari hasil penelitian diperoleh kesimpulan bahwa variabel Kepemimpinan secara parsial berpengaruh signifikan terhadap variabel Kepuasan Kerja Karyawan SMK Muhammadiyah 4 Jakarta. Hal ini menunjukkan bahwa kepemimpinan berperan penting dalam sebuah organisasi, jika kepemimpinan meningkat maka kepuasan kerja juga akan meningkat.

2. Pengaruh Komunikasi $\left(\mathrm{X}_{2}\right)$ terhadap Kepuasan Kerja $(\mathrm{Y})$ menunjukkan bahwa variabel komunikasi $\left(\mathrm{X}_{2}\right)$ nilai $t_{\text {hitung }}>\mathrm{t}_{\text {tabel }}(4,057>2,012)$ Ho ditolak dan nilai signifikansi $(0,000$ $<0,05)$ maka Ha diterima, yang artinya komunikasi berpengaruh signifikansi terhadap kepuasan kerja.

Dari hasil penelitian diperoleh kesimpulan bahwa variabel Komunikasi secara parsial berpengaruh signifikan terhadap variabel Kepuasan Kerja Karyawan SMK Muhammadiyah 4 Jakarta. Hal ini menunjukkan bahwa komunikasi berperan agar penyampaian informasi dalam suatu organisasi berjalan lancar, jika komunikasi meningkat maka kepuasan kerja juga akan meningkat.

3. Pengaruh Kompetensi $\left(\mathrm{X}_{3}\right)$ terhadap Kepuasan Kerja $(\mathrm{Y})$ menunjukkan bahwa variabel kompetensi $\left(\mathrm{X}_{3}\right)$ nilai $\mathrm{t}_{\text {hitung }}<\mathrm{t}_{\text {tabel }}(1,213<2,012)$ Ho diterima dan nilai signifikansi $(0,231>$ $0,05)$ maka Ha ditolak, yang artinya kompetensi tidak berpengaruh signifikansi terhadap kepuasan kerja.

Dari hasil penelitian diperoleh kesimpulan bahwa variabel Kompetensi secara parsial tidak berpengaruh signifikan terhadap Kepuasan Kerja Kaeyawan SMK Muhammadiyah 4 Jakarta. Hal ini menunjukkan jika kompetensi menurun maka kepuasan kerja juga akan menurun.

4. Pengaruh Kepemimpinan $\left(\mathrm{X}_{1}\right)$, Komunikasi $\left(\mathrm{X}_{2}\right)$, dan Kompetensi $\left(\mathrm{X}_{3}\right)$ Terhadap Kepuasan Kerja (Y) hasil uji $F$ menunjukkan bahwa nilai $F_{\text {hitung }}$ 9,551 > nilai $F_{\text {tabel }}$ 2,81 dan nilai probabilitas (signifikan) sebesar 0,000 karena nilai sig $0,000<0,05$. Maka Hodditolak dan $\mathrm{H}_{\mathrm{a} 4}$ diterima. Dengan demikian dapat disimpulkan bahwa terdapat pengaruh secara signifikan antara Kepemimpinan $\left(\mathrm{X}_{1}\right)$, Komunikasi $\left(\mathrm{X}_{2}\right)$, dan Kompetensi $\left(\mathrm{X}_{3}\right)$ terhadap Kepuasan Kerja (Y).

Artinya, dari hasil penelitian dapat diketahui bahwa Kepemimpinan, Komunikasi, dan Kompetensi secara simultan memiliki pengaruh terhadap Kepuasan Kerja Karyawan SMK Muhammadiyah 4 Jakarta. Hal ini menunjukkan bahwa Kepuasan Kerja dapat ditingkatkan melalui proses kepemimpinan, komunikasi, dan kompetensi sesuai dengan keahliannya.

\section{E. Saran}

Berdasarkan hasil penelitian di atas mengenai Pengaruh Kepemimpinan, Komunikasi, dan Kompetensi Terhadap Kepuasan Kerja Karyawan SMK Muhammadiyah 4 Jakarta, peneliti memberikan saran sebagai bahan masukan dan pertimbangan:

\section{Bagi Pegawai}

Hasil penelitian ini diharapkan dapat dijadikan masukan bagi pegawai untuk terus menjalin hubungan kerja yang baik terhadap pimpinan, rekan kerja, dan dengan bawahan sehingga terciptanya lingkungan kerja yang baik dan dapat meningkatkan kinerjanya.

\section{Bagi Sekolahan}


Hasil penelitian ini diharapkan dapat dijadikan masukan bagi sekolahan untuk meningkatkan Kepuasan Kerja Karyawannya melalui Kepemimpinan, Komunikasi, dan Kompetensiagar mencapai tujuan yang telah ditetapkan.

\section{Bagi Pemerintah}

Diharapkan pemerintah dapat menghimbau terhadap yayasan yang berdiri di Indonesia, terutama agar mengikuti prosedur dan ketentuan sesuai dengan ketetapan yang telah dibuat oleh pemerintah. Terutama dalam menerapkan kepemimpinan, komunikasi, dan kompetensi agar selalu ditempatkan sesuai dengan keahlian yang membuat karyawan memiliki kepuasan kerja.

\section{Bagi Peneliti Selanjutnya}

Untuk peneliti selanjutnya diharapkan penelitian ini dapat menjadi bahan acuan ataupun pertimbangan bagi pembaca karya ilmiah lainnya, dan agar peneliti selanjutnya dapat menambah jumlah variabel bebas dengan yang baru, dengan menggunakan data yang lebih akurat, jumlah data yang banyak, serta rentang waktu yang lebih panjang, sehingga memungkinkan hasil penelitian terhadap variabel terikat Kepuasan Kerja dapat dijelaskan dengan lebih baik. Menambah variabel lain yang dapat mempengaruhi Kepuasan Kerja Karyawan selain Kepemimpinan, Komunikasi, dan Kompetensi. Misalnya menambah variabel Motivasi Kerja, Pelatihan dan Lingkungan Kerja.

\section{DAFTAR PUSTAKA}

Afandi, Pandi. 2016. Concept \& Indikator Human Resources Management For Management Research. Yogyakarta: Deepublish.

Busro, Muhammad. 2018. Teori-Teori Manajemen Sumber Daya Manusia. Jakarta: Prenadamedia Group.

Cangara, Hafidz. 2018. Pengantar Ilmu Komunikasi. Jakarta: PT. Raja Grafindo Persada. Effendy, Onong. 2017. Komunikasi Teori dan Praktek. Jakarta: Grasindo Rosdakarya.

Mangkunegara, A.A. Anwar Prabu. 2017. Manajemen Sumber Daya Manusia Perusahaan. Bandung: PT. Remaja Rosdakarya.

Ngalimun. 2017. Ilmu Komunikasi Sebuah Pengantar Praktis. Yogyakarta: Pustaka Baru Press.

Priyatno. Dwi. 2017. Panduan Olah Data Menggunakan SPSS. Yogyakarta: Andi.

Robbins, Stephen P. \& Mary Coulter. 2016. Manajemen. Jakarta: Erlangga.

Sinambela, Lijan Poltak. 2012. Kinerja Pegawai. Yogyakarta: Graha Ilmu.

Sinambela, Lijan Poltak. 2018. Manajemen Sumber Daya Manusia. Jakarta: Bumi Aksara.

Sudaryo, Aribowo, Sofiati. 2018. Manajemen Sumber Daya Manusia(Kompensasi Tidak Langsung Dan Lingkungan Kerja Fisik). Yogyakarta: Penerbit Andi.

Sugiyono. 2018. Metode Penelitian Kuantitatif, Kualitatif dan R\&D.

Sutrisno, Edy. 2017. Manajemen Sumber Daya Manusia. Jakarta: Kencana.

Wibowo. 2016. Manajemen Perubahan. Jakarta: Rajawali Pers.

Wibowo. 2017. Perilaku Dalam Organisasi. Depok: Rajawali pers

Hasrudy, Tanjung. 2016. Pengaruh Disiplin Kerja, Kompetensi, dan Budaya Organisasi Terhadap Kepuasan Kerja Pegawai Pada Dinas Perkebunan Sumatera Utara. Jurnal Konsep Bisnis dan Manajemen. Vol. 3 No. 1.

Yopi, Yunsepa. 2018. Pengaruh Lingkungan Kerja, Komunikasi, Kompetensi, dan Kompensasi Terhadap Kepuasan Kerja Karyawan Pabrik SOGM Pada PT. Perkebunan Minanga Ogan Region SUMSEL-Lampung. Jurnal Ecoment Global. Vol. 3 No. 1.

I, Wayan, Roy, Sarlita, Putra. 2019. Pengaruh Komunikasi, Budaya Organisasi, dan Lingkungan Kerja Fisik Terhadap Kepuasan Kerja Karyawan Ramada Bintang Bali. Jurnal Manajemen. Vol. 8 No. 3. 